\title{
PENGEMBANGAN MEDIA PEMBELAJARAN INTERAKTIF BERBASIS STRATEGI METAKOGNITIF UNTUK MENINGKATKAN KEMAMPUAN BERPIKIR KRITIS SISWA
}

\author{
Asrean Hendi ${ }^{1}$, Caswita ${ }^{2}$, Een Yayah Haenilah ${ }^{3}$ \\ ${ }^{1,2,3}$ Prodi Magister Pendidikan Matematika, FKIP, Universitas Lampung, Jln. Prof. Dr. Ir. Sumantri \\ Brojonegoro No. 1, Kota Bandar Lampung, Provinsi Lampung, Indonesia. \\ hendi302006@gmail.com
}

\begin{abstract}
This present study aims to develop metacognitive strategies based interactive learning media. This interactive learning media was developed as a support to toward the student's critical thinking skill. This interactive learning media is in the form of powerpoint. The development research model use DDD-E model. The developing phase starts from deciding, designing, developing and evaluating. The subject of the study were students of class X TKJ at SMK Harapan Bangsa Ulubelu, Tanggamus district, in 2019-2020 accademic year. The data of the research was obtained through observation, interview, and questionnaires on teacher responses to learning media and critical thinking ability test. The developed interactive learning media is valid according to media experts in terms of supporting theories and the structure of developing metacognitive strategies based interactive learning media to improve students' critical thinking ability. The field test result showed that the critical thinking skill of the students who applied metacognitive strategies based interactive learning media were higher than students who did not apply metacognitive-based interactive learning media. In conclusion, the developed metacognitive based strategies learning media is more effective to improve the students' critical thinking ability.
\end{abstract}

Keywords: Metacognitive strategies based interactive learning media, critical thinking skill

\begin{abstract}
Abstrak
Penelitian ini bertujuan untuk mengembangkan media pembelajaran interaktif berbasis strategi metakognitif. Media pembelajaran interaktif ini dikembangkan sebagai penunjang untuk meningkatkan kemampuan berpikir kritis siswa. Media interaktif ini berbentuk file persentasi dalam bentuk powerpoint. Model penelitian pengembangan yang digunakan adalah Model DDD-E oleh Ivers dan Barron. Tahapan pengembangan peneltian dimulai dari decide, design, develope, dan evaluate. Subjek penelitian ini adalah siswa kelas X TKJ di SMK Harapan Bangsa Ulubelu Kabupaten Tanggamus, tahun pelajaran 2019-2020. Data penelitian diperoleh melalui observasi, wawancara, angket respon guru terhadap media pembelajaran, dan tes kemampuan berpikir kritis siswa. Media pembelajaran interaktif yang dikembangkan telah valid menurut ahli media dari segi teori pendukung dan struktur pengembangan media pembelajaran interaktif berbasis metakognitif untuk meningkatkan kemampuan berpikir kritis siswa. Hasil uji di lapangan menunjukkan bahwa kemampuan berpikir kritis siswa yang menggunakan media pembelajaran interaktif berbasis strategi metakognitif lebih tinggi dari pada kemampuan berpikir kritis siswa yang tidak menggunakan media pembelajaran interaktif berbasis stategi metakognitif. Oleh karenanya dapat disimpulkan bahwa media pembelajaran interaktif berbasis metakognitif yang dikembangkan lebih efektif untuk meningkatkan kemampuan berpikir kritis siswa.
\end{abstract}

Kata kunci: Media pembelajaran interaktif berbasis strategi metakognitif, kemampuan berpikir kritis.

\section{PENDAHULUAN}

Salah satu aspek penting pembangunan sumber daya manusia yang berkualitas adalah aspek pendidikan. Tanpa pendidikan yang baik sumber daya manusia tidak akan berkembang dan tidak akan mampu bersaing dengan bangsa lain. Pendidikan merupakan kebutuhan setiap manusia sepanjang hayat. Tanpa pendidikan, manusia sulit berkembang sehingga pendidikan harus diarahkan untuk menghasilkan manusia yang berkualitas, mampu bersaing serta mempunyai budi pekerti yang baik.

Melalui pendidikan, manusia dapat belajar agar memiliki keterampilan sehingga mampu 
menjadi pribadi yang terampil, kreatif, dan inovatif. Pendidikan dapat diperoleh melalui lembaga formal maupun non formal yang mengarah kepada pendidikan sepanjang hayat. Pendidikan melalui lembaga formal dapat diperoleh di sekolah, sedangkan pendidikan non formal dapat diperoleh dari kegiatan di luar sekolah, contohnya kursus keterampilan maupun kegiatan komunitas yang ada di sekitar lingkungan. Pendidikan formal yang diperoleh di sekolah, mempelajari bermacam macam mata pelajaran, salah satu mata pelajaran adalah matematika.

Matematika memiliki peranan penting dalam kemajuan peradaban manusia. Matematika telah dikembangkan oleh para matematikawan mulai dari zaman mesir kuno, babylonia, hingga yunani kuno. Pada zaman tersebut matematika dipelajari, dikembangkan, dan digunakan untuk menyelesaikan permasalahan dalam kehidupan sehari-hari, seperti masalah perdagangan, pengukuran tanah, pelukisan, konstruksi, dan astronomi. Hingga sekarang pun matematika masih tetap digunakan untuk hal-hal tersebut, baik untuk menyelasaikan permasalahan dalam kehidupan sehari-hari atau membantu dalam mengembangkan disiplin ilmu lain.

Pelajaran matematika menghadapkan siswa pada permasalahan yang memerlukan kecermatan dan ketelitian dalam memecahkan suatu persoalan matematika. Untuk memecahkan persoalan matematika tersebut diperlukan kemampuan-kemampuan dasar yang harus dimiliki oleh para siswa agar dapat menghasilkan jawaban-jawaban yang tepat dan kesimpulan yang logis. Kemampuan dasar yang harus dimiliki siswa adalah salah satunya kemampuan berpikir kritis. Siswa yang memiliki kemampuan berpikir kritis dapat meningkatkan potensi intelektualnya, dan juga rasa percaya diri dalam menyelesaikan persoalan matematika, tidak hanya itu siswa tidak akan takut dan ragu ketika dihadapkan pada masalah nyata dikehidupan sehari-hari.

Kemampuan berpikir kritis adalah kemampuan yang dimiliki oleh setiap individu untuk menyelesaikan sebuah masalah dengan berfokus kepada proses dan langkah-langkah yang diambil secara teliti yang dapat dipertanggung jawabkan. Berpikir kritis mengarah pada kegiatan menganalisa suatu gagasan secara sistematis dan spesifik, membedakan sesuatu hal secara cermat dan teliti, mengidentifikasi, mengkaji, dan mengembangkan proses berpikir tersebut dengan menggunakan logika dan bukti ke arah yang lebih sempurna. Hal ini sejalan dengan apa yang dikemukakan oleh (Tinio, 2003) yang menyatakan bahwa berpikir kritis berkaitan dengan kemampuan mengidentifikasi, menganalisis dan memecahkan masalah secara kreatif dan berpikir logis sehingga menghasilkan pertimbangan dan keputusan yang tepat.

(Peter, 2012) menyatakan berpikir kritis merupakan kemampuan yang sangat dibutuhkan dalam seluruh sistem pembelajaran saat ini. Tujuan menanamkan keterampilan berpikir kritis dalam pembelajaran matematika di kelas adalah untuk memposisikan siswa bukan sebagai penerima informasi saja melainkan informasi yang diterima tersebut dapat menggunakannya.

(Ennis, 1996) menyatakan bahwa berpikir kritis menekankan pada pemikiran yang rasional dan reflektif sehingga dapat mencapai proses pengambilan keputusan. Ini berarti ketika memecahkan suatu masalah perlu adanya pertimbangan yang masuk akal dan reflektif sehingga dapat mengambil 
keputusan tentang apa solusi yang tepat dan benar yang dapat digunakan untuk menyelesaikan masalah tersebut. Pendapat lain yang dikemukakan oleh (Slavin, 2006) menyatakan bahwa berpikir kritis merupakan kemampuan mengambil keputusan secara rasional tentang apa yang harus dilakukan atau apa yang harus diyakini.

(Malahayati et al., 2015) menyatakan bahwa Berpikir kritis berhubungan positif dengan kemampuan metakognitif. Hal ini didasari oleh hasil penelitiannya bahwa besar sumbangan efektif keterampilan metakognitif terhadap hasil belajar sebesar $28.86 \%$ dan sumbangan efektif kemampuan berpikir kritis sebesar $46.16 \%$, sehingga total sumbangan efektif adalah $75.02 \%$. Hasil penelitian ini membuktikan bahwa keterampilan metakognitif dan kemampuan berpikir kritis secara bersama-sama memberikan sumbangan efektif yang sangat besar terhadap hasil belajar siswa.

Upaya melibatkan metakognitif dalam berbagai kegiatan pembelajaran dapat memberikan manfaat dalam proses peningkatan kualitas dan hasil pembelajaran khususnya kemampuan berpikir kritis siswa. Hal ini didukung oleh pendapat Schoen (Magno, 2010) yang menyatakan bahwa keterampilan berpikir kritis siswa dapat dikembangkan dan difasilitasi melalui metakognitif, karena di dalam metakognitif terdapat kemampuan mengendalikan pengetahuan dan pemikiran seseorang (metacognitive control) dan proses ini mengarahkan seseorang untuk berpikir kritis.

Brown (Magno, 2010) menyatakan berpikir kritis mustahil dicapai tanpa adanya metakognitif. Hal ini karena untuk mengembangkan kemampuan berpikir kritis diperlukan tingkat kemampuan kognitif yang lebih tinggi daripada sekedar pengolahan informasi. Misalnya informasi apa yang ada dalam buku teks, apa yang harus dilakukan dan berapa lama waktu yang dibutuhkan untuk menyelesaikan suatu masalah.

(Tavakoli \& Koosha, 2016) menjelaskan definisi metakognisi yang dikemukakan pertama kali oleh Flavell bahwa "Metacognitionas knowledge about cognition and control of cognition". Metakognitif sebagai pengetahuan tentang kognisi dan kontrol dari kognisi. (Schraw, 1998) berpendapat bahwa Metakognitif merupakan bagian penting kesuksesan dalam belajar, karena memungkinkan individu lebih baik dalam mengelola keterampilan kognitif mereka dan untuk menentukan kelemahan yang dapat diperbaiki dengan membangun keterampilan berpikir yang baru.

(Saricam \& Ogurlu, 2015) mendefinisikan "Metacognition is thinking about thinking".Metakognitif adalah berpikir tentang berpikir. (Özsoy \& Ataman, 2017) menyatakan "Metacognition means an individual's awareness of his own thinking processes and his ability to control these processes". Metakognitif berarti kesadaran individu dari proses berpikirnya sendiri dan kemampuannya untuk mengendalikan proses berpikirnya.

Keterampilan berpikir kritis siswa dapat dikembangkan dengan penggunaan media pembelajaran yang tepat seperti yang dikemukakan oleh (Hasnunidah, 2011) bahwa keahlian seorang guru dalam memilih media pembelajaran yang tepat adalah salah satu faktor yang menentukan keberhasilan pengembangan keterampilan berpikir kritis siswa, hal tersebut sesuai dengan pendapat (Mayer, 2002) bahwa keterampilan berpikir kritis siswa dapat dikembangkan dengan penggunaan 
media pembelajaran yang tepat, pemilihan media pembelajaran yang tepat dapat menetukan keberhasilan pengembangan keterampilan berpikir kritis siswa.

Menurut (Wahidin \& Syaefuddin, 2018) media merupakan sesuatu yang bersifat menyalurkan pesan dan dapat merangsang pikiran, perasaan, dan kemauan audien (siswa) sehingga dapat mendorong terjadinya proses belajar pada dirinya. Kemudian Miarso (Ardhianti, 2015) mengemukakan bahwa media pembelajaran adalah segala sesuatu yang digunakan untuk menyalurkan pesan serta dapat merangsang pikiran, perasaan, perhatian, dan kemauan siswa sehingga dapat mendorong terjadinya proses belajar yang disengaja, bertujuan, dan terkendali.

Menurut (Munadi, 2013) media pembelajaran adalah segala sesuatu yang dapat menyampaikan dan menyalurkan pesan dari sumber secara terencana sehingga tercipta lingkungan belajar yang kondusif di mana penerimanya dapat melakukan proses belajar secara efisien dan efektif.

(Harto, 2008) menggungkapkan bahwa pengertian media interaktif terkait dengan komunikasi dua arah atau lebih dari komponen-komponen komunikasi. Sedangkan menurut (Miarso, 2005), karakteristik terpenting dalam media pembelajaran interaktif yaitu siswa tidak hanya memperhatikan penyajian materi atau objek tetapi juga harus ikut berinteraksi selama pembelajaran. Media interaktif menurut (Suheri, 2006) adalah suatu media yang dilengkapi dengan alat pengontrol yang dapat dioperasikan oleh pengguna, sehingga pengguna dapat memilih apa yang dikehendaki untuk proses selanjutnya. Aspek interaktif pada media ini dapat berupa navigasi, simulasi, permainan dan latihan soal.

Beberapa informasi awal yang diperoleh di SMK Harapan Bangsa Ulubelu Kabupaten Tanggamus diantaranya bahwa rata-rata nilai Ujian Nasional mata pelajaran matematika kelas IX adalah 38,37 dengan standar deviasi 10,95. Rata-rata nilai tersebut berada di bawah Kriteria Ketuntasan Minimal (KKM) beberapa sekolah yaitu rata-rata 60. Selain itu berdasarkan hasil wawancara dengan beberapa guru pengampu mata pelajaran matematika di kelas $\mathrm{X}$ diperoleh informasi bahwa siswa mengalami kesulitan dalam belajar matematika. Hal ini berawal paradigma yang muncul dan berkembang di kalangan siswa bahwa matematika dianggap adalah salah satu mata pelajaran yang sulit dipahami. Hal ini disebabkan dalam pembelajaran matematika siswa hanya terfokus pada hafalan rumus dalam menyelesaikan masalah atau soal. Mereka beranggapan bahwa hanya dengan menghafal rumus sudah dapat menemukan solusi, sedangkan fokus dalam menghafal rumus matematika menunjukkan tingkat kemampuan berpikir siswa yang rendah karena belum tentu dengan menghafal rumus dapat menyelesaikan masalah dalam matematika.

Selain itu guru pengampu mata pelajaran matematika kelas X SMK Harapan Bangsa Ulubelu kabupaten Tanggamus menginformasikan juga bahwa dalam proses pembelajaran matematika guru cenderung menggunakan pembelajaran dengan metode ceramah yang berpusat pada guru bukan berpusat pada siswa, tanpa didukung dengan penggunaan media pembelajaran untuk membantu siswa agar lebih memahami dan memperjelas tentang materi pembelajaran yang sedang disampaikan. Guru terbiasa menjelaskan definisi, teorema, ataupun rumus-rumus yang dilanjutkan dengan pemberian 
contoh soal dan latihan yang ada di lembar kerja siswa ataupun buku-buku cetak pegangan siswa yang tersedia. Disamping itu pula, berdasarkan hasil wawancara tersebut, juga menunjukkan bahwa guru masih mengalami kebingungan dan kesulitan dalam menentukan dan menggunakan media pembelajaran yang tepat atau sesuai saat pembelajaran berlangsung, terlebih media pembelajaran berbasis Teknologi Informasi dan Komunikasi (TIK). Hal ini mengakibatkan siswa merasa jenuh, bosan dan kompetensi yang ada pada siswa belum dapat tergali secara maksimal.

Oleh karena itu, diperlukan suatu pendekatan yang bisa diterima dan dimengerti oleh siswa dengan baik, hal ini dimaksudkan untuk mengatasi hambatan-hambatan yang terjadi. Salah satu pendekatan yang bisa digunakan yaitu dengan menggunakan media pembelajaran interaktif. Media pembelajaran interaktif yang digunakan dalam pembelajaran dapat menjadikan wahana bagi siswa untuk memahami konsep-konsep dalam pembelajaran yang masih bersifat abstrak dapat menjadi gambaran yang lebih konkrit. Selain itu penggunaan media pembelajaran dengan berbasis strategi metakognitif dapat dijadikan solusi atau alternatif untuk meningkatkan kemampuan berpikir krtis siswa dalam pembelajaran.

\section{METODE}

Jenis penelitian ini merupakan penelitian pengembangan. Model penelitian pengembangan yang digunakan dalam penelitian ini adalah model Research and Development $(R \& D)$ yang merujuk pada model Ivers dan Barron atau lebih dikenal dengan model pengembangan DDD-E (Decide, Design, Develop, Evaluate). Menurut (Ivers \& Barron, 2002) Pengembangan media interaktif menggunakan model DDD-E terdiri atas 4 tahapan yaitu:

1) Decide atau menetapkan tujuan dan materi program. Tahap decide merupakan tahap untuk merencanakan produk media interaktif. Dalam tahap ini dilakukan beberapa langkah yaitu : Determine project goals, Brainstorm Content, dan Conduct Research.

2) Design atau desain yaitu membuat struktur program. Tahap Design merupakan tahap berpikir visual karena menghasilkan cetak biru untuk keseluruhan produk media interaktif dalam bentuk Outline materi, tampilan layout, flowchart dan storyboard.

3) Develope atau mengembangkan adalah memproduksi elemen media interaktif dan membuat tampilan media. Dalam tahapan develope pengembang mulai mengembangkan proyek media yang akan dibuat, yang meliputi produksi komponen media seperti teks, grafik, animasi, audio dan video.

4) Evaluate atau mengevaluasi yaitu mengecek seluruh proses desain dan pengembangan .Tahapan evaluasi sebenarnya telah diintegrasikan ke dalam setiap tahapan model pengembangan DDD-E. Namun dalam tahapan evaluasi ini, dilakukan pengulasan kembali rancangan produk yang mulai dikembangkan sebelum dilakukannya tahapan review dan validasi oleh ahli materi dan ahli media yang telah ditentukan. 


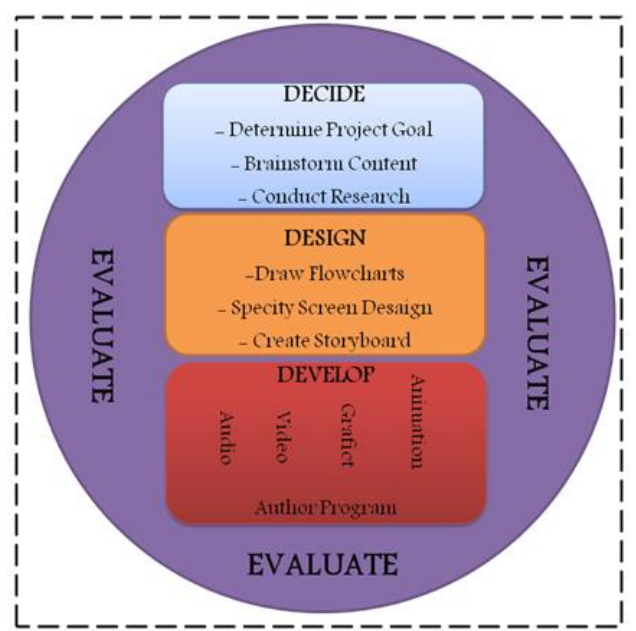

Gambar 1. Tahapan Aktivitas Penelitian pengembangan Model DDD-E

Penelitian dilaksanakan di kelas X jurusan Teknik Komputer dan Jaringan (TKJ). Penelitian dilaksanakan pada dua kelas penelitian, yaitu kelas X TKJ 1 sebagai kelas eksperimen dan kelas X TKJ 2 sebagai kelas kontrol. Pada kelas eksperimen pembelajarannya dengan menggunakan Media pembelajaran interaktif berbasis strategi metakognitif, sedangkan pada kelas kontrol tidak menggunakan media pembelajaran interaktif berbasis strategi metakognitif. Penelitian ini dilaksanakan di SMK Harapan Bangsa Ulubelu Kabupaten Tanggamus pada Semester Genap tahun pelajaran 2019-2020. Pemilihan tempat penelitian ini dilakukan berdasarkan informasi dari guru di SMK tersebut bahwa di sini belum pernah dilakukan penelitian sejenis ini.

Instrumen yang digunakan pada penelitian ini terdiri dari dua jenis instrumen, yaitu nontes dan tes. Instrumen nontes berupa pedoman wawancara, observasi, dan angket yang berupa lembar validasi oleh ahli materi, validasi oleh ahli media, angket respon guru terhadap media pembelajaran interaktif. Instrumen tes berupa soal uraian yang terdiri dari 8 soal yang diberikan pada pertemuan awal (Preetest) dan pertemuan akhir (Posttest) pada kelas eksperimen dan kelas kontrol untuk mengetahui uji efektifitas produk yang digunakan.

Teknik analisis data dalam penelitian pengembangan ini yaitu menggunakan analisis kualitatif yang didapatkan dari hasil observasi, wawancara, dan angket. Sedangkan analisis kuantitatif diperoleh melalui hasil tes kemampuan berpikir kritis siswa pada awal pertemuan pembelajaran (preetest) dan akhir pertemuan pembelajaran (posttest) pada kelas eksperimen dan kontrol.

\section{HASIL}

Penelitian pengembangan ini dilakukan sebanyak 7 kali pertemuan dengan 6 kali pertemuan untuk pelaksanaan pembelajaran serta satu pertemuan untuk tes kemampuan berpikir kritis siswa. Hasil penelitian ini dijelaskan berdasarkan tahapan penelitian dan pengembangan menurut Ivers \& Barron sebagai berikut ini: 


\section{Decide (Menetapkan)}

Dalam tahapan decide terdiri atas penentuan tujuan instruksional yang akan dicapai, menentukan tema media yang akan dikembangkan, mengembangkan kemampuan prasyarat atau kemampuan awal yang dimiliki siswa dalam menjalankan program media yang akan dikembangkan, serta menilai sumber daya yang meliputi sarana dan prasarana yang mendukung dalam pengembangan media yang akan dilakukan. Tahap decide merupakan tahap awal untuk merencanakan produk media interaktif pembelajaran yang digunakan dalam pembelajaran. Tahap ini diawali dengan megumpulkan berbagai informasi dari lapangan yang dapat digunakan untuk perencanaan pengembangan produk dengan harapan dapat mengatasi masalah yang ada, diantaranya yaitu menentukan tujuan pengembangan produk dengan menganalisis kompetensi inti, kompetensi dasar, dan indikator pencapaian berdasarkan kurikulum yang berlaku, yaitu kurikulum 2013.

\section{Design (Mendesain)}

Pada tahap design merupakan tahap penuangan ide karena menghasilkan desain untuk keseluruhan produk multimedia dalam bentuk garis besar isi, outline materi, tampilan atau layout, flowchart dan storyboard. Sebelum memulai mengembangkan media, pengembang harus mengklasifikasikan elemen- elemen yang akan dimasukkan dalam media pembelajaran yang cocok digunakan seperti mengatur materi, suara dan urutan unsur media yang tergambar dalam flowchart. Program ini berbentuk file persentasi berbentuk powerpoint. . Program ini dipilih karena memang di SMK Harapan Bangsa Ulubelu, masih jarang guru menggunakan media ini untuk pembelajaran, disamping itu pembuatannya lebih mudah, dan siswa juga lebih mudah menggunakannya. Program ini berkapasitas kurang lebih $30 \mathrm{MB}$, sehingga sangat mudah distribusikan ke computer.

\section{Develope (Mengembangkan)}

Pada tahap develop (mengembangkan), tahap ketiga dari model DDD-E adalah pengembangan, yang meliputi produksi komponen media seperti teks, grafik, animasi, audio dan video atau memproduksi elemen media atau membuat tampilan media. Pada tahap ini dilakukan uji coba kelayakan kepada ahli materi, ahli media. Kemudian media interaktif yang sudah dikembangkan dan mendapat perbaikan atau revisi dan dinyatakan layak oleh ahli media dan ahli materi kemudian diujicobakan kepada siswa SMK Harapan Bangsa Ulubelu kelas X. Adapun contoh bentuk tampilan media pembelajaran interaaktif ini adalah sebagai berikut : 


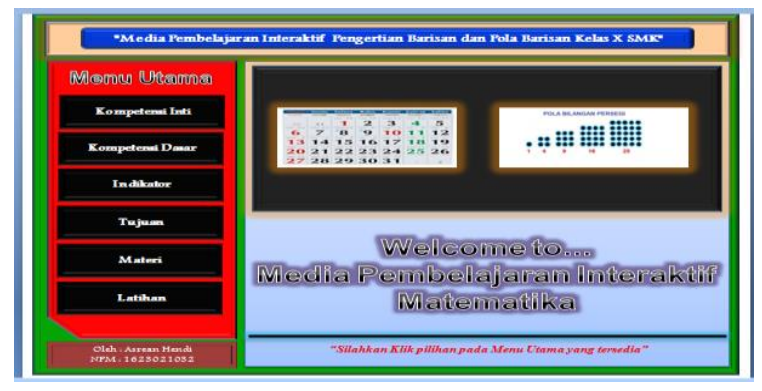

(a)

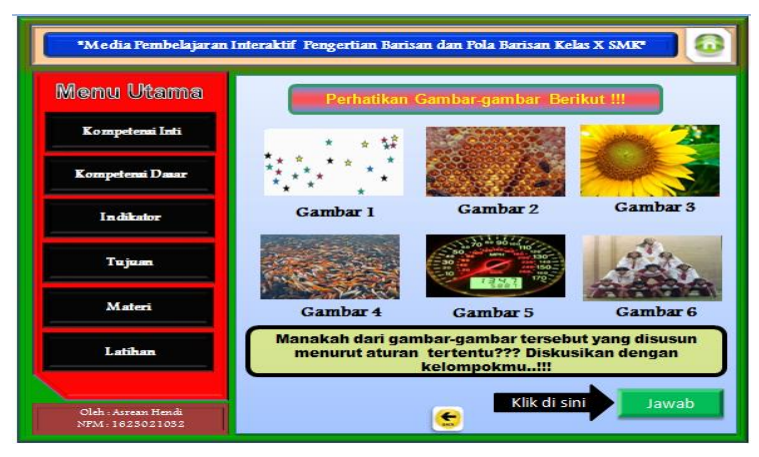

(c)

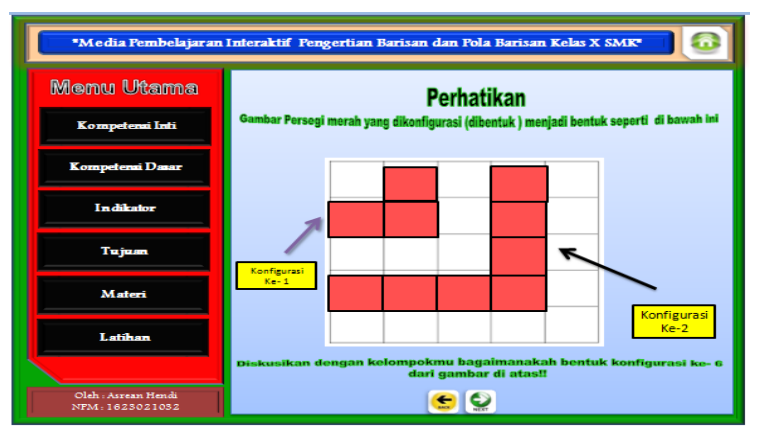

(e)

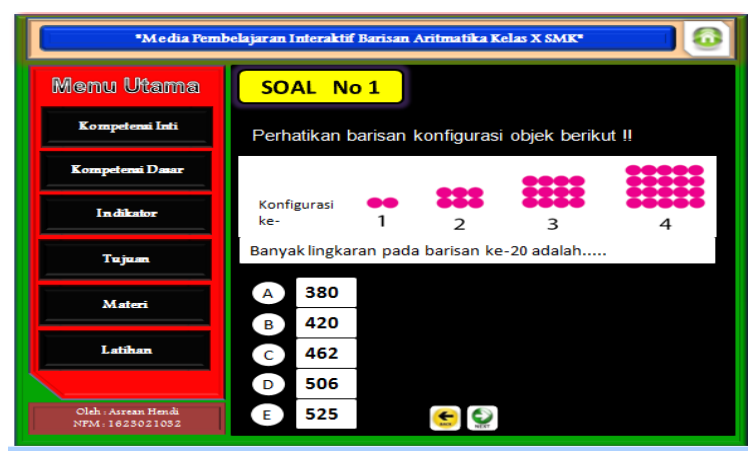

$(\mathrm{g})$

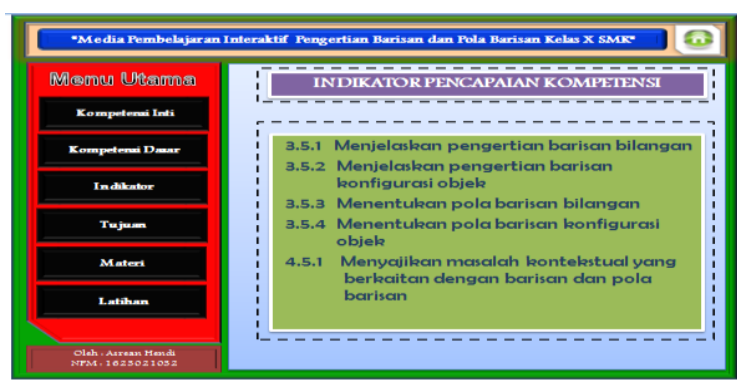

(b)

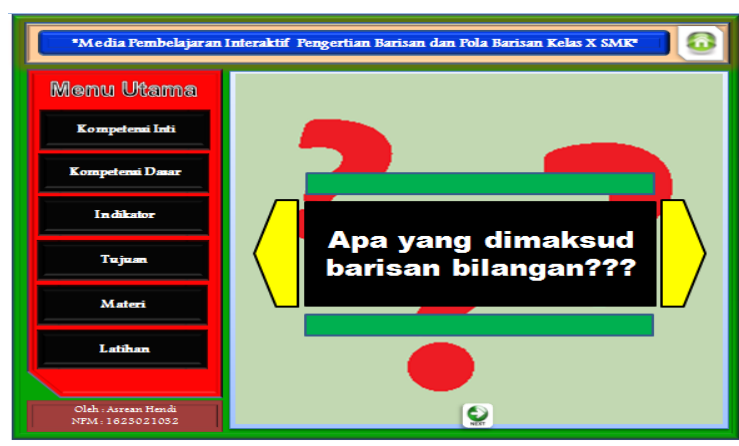

(d)

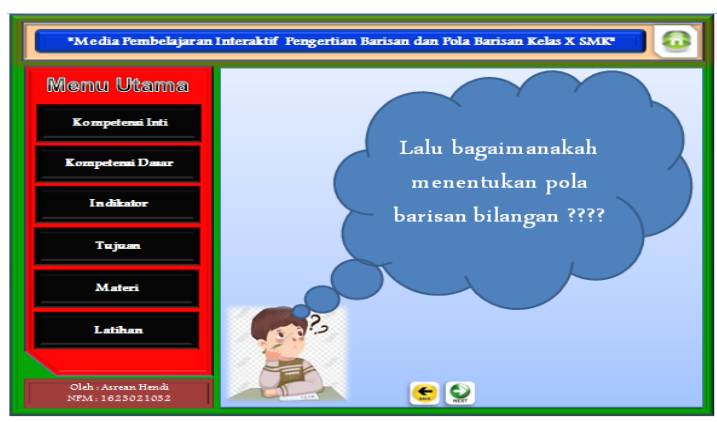

(f)

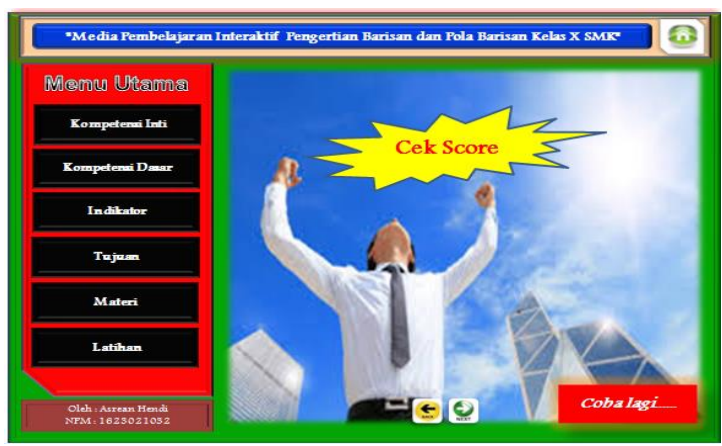

(h)

Gambar 2. Contoh Tampilan Media Interaktif : (a) Menu Utama ; (b) Indikator Pencapaian Kompetensi; (c) (d) (e) (f) Materi Pembelajaran ; (g) Latihan Soal; (h) Cek Skor Latihan 
Materi dalam penelitian ini adalah barisan dan deret. Produk yang telah dikembangkan memerlukan ujicoba apakah media interaktif yang dikembangkan layak dan efektif sebelum digunakan dalam proses pembelajaran. Uji kelayakan dilakukan dengan validasi ahli materi, ahli media. Sedangkan uji coba keefektifan media dilakukan dengan uji coba dilapangan dengan mengambil data perbandingan antara kelas eksperimen dan kelas kontrol.

Hasil perhitungan validitas oleh ahli materi diperoleh nilai presentase sebesar 84,01\% yang termasuk dalam kategori Baik. Sedangkan hasil validitas yang dilakukan oleh ahli media yang menunjukkan hasil presentase sebesar $95,45 \%$ yang dapat disimpulkan bahwa nilai tersebut termasuk dalam kategori Sangat Baik. Dari hasil tersebut dapat disimpulkan bahwa media yang di validasi dapat dikatakan layak untuk digunakan dalam proses pembelajaran. Sebelum dilakukan tes terhadap siswa, perlu dilakukan uji validitas dan reliabelitas untuk menguji kevalidan setiap butir soal, Soal yang dinyatakan valid apabila $r_{\text {hitung }}>r_{\text {tabel }}$. Dari hasil uji validitas butir soal didapat $r_{\text {hitung }}$ dalam tabel 1 berikut :

Tabel 1.

Hasil Uji Validitas Instrumen Tes Kemampuan Berpikir Kritis

\begin{tabular}{|c|c|c|c|}
\hline Nomor Soal & $\mathbf{r}_{\mathbf{x y}}$ & Kriteria & Interpretasi Validitas \\
\hline 1 & 0,741 & Tinggi & Tepat/ Baik \\
\hline 2 & 0,767 & Tinggi & Tepat/ Baik \\
\hline 3 & 0,712 & Tinggi & Tepat/ Baik \\
\hline 4 & 0,756 & Tinggi & Tepat/ Baik \\
\hline 5 & 0,703 & Tinggi & Tepat/ Baik \\
\hline 6 & 0,742 & Tinggi & Tepat/ Baik \\
\hline 7 & 0,712 & Tinggi & Tepat/ Baik \\
\hline 8 & 0,719 & Tinggi & Tepat/ Baik \\
\hline
\end{tabular}

$r_{\text {tabel }}=0,432$, karena $r_{\text {hitung }}>r_{\text {tabel }}$, maka dapat disimpulkan bahwa kedelapan butir soal di atas valid. Kemudian soal yang valid dihitung reliabilitas soal dengan menggunakan rumus $r_{11}$. Dalam pemberian interprestasi terhadap koefisien reliabilitas tes (Sudijono, 2011: 208) menggunakan patokan sebagai berikut :

1) Apabila $r_{11}$ sama dengan atau lebih besar dari pada 0,7 berarti tes hasil belajar yang sedang diuji reliabilitasnya dinyatakan telah memiliki reliabilitas yang tinggi (reliabel).

2) Apabila $r_{11}$ lebih kecil dari pada 0,7 berarti tes hasil belajar yang sedang diuji reliabilitasnya dinyatakan tidak memiliki reliabilitas yang tinggi (un-reliabel).maka dapat disimpulkan bahwa soal test dapat dikatakan reliable.

Dari perhitungan diperoleh $r_{11}=0,856$. Karena $r_{11}>0,7$, sesuai kriteria di atas maka tes hasil belajar yang sedang diuji dinyatakan reliabel. 
Data yang diperoleh dari pretest dan postest dianalisis menggunakan uji statistik induktif. Sebelum melakukan analisis uji statistik perlu dilakukan uji prasyarat, yaitu uji normalitas dan homogenitas. Data uji normalitas diperoleh dari hasil pretest dan posttest kelas X TKJ 1 sebagai kelas eksperimen dan kelas X TKJ 2 sebagai kelas kontrol. Berikut hasil uji normalitas sebaran data pretest dan posttest pada kelas eksperimen maupun kelas kontrol dibantu program SPSS pada Tabel 1.

Tabel 2.

Hasil Uji Normalitas Kelas Eksperimen dan Kelas Kontrol

\begin{tabular}{|l|c|c|}
\hline Data & Hasil (Sig.) & Keterangan \\
\hline Pretest Kelas Eksperimen & 0,087 & Sig. $>0,05$, berdistribusi normal \\
\hline Pretest Kelas Kontrol & 0,069 & Sig. $>0,05$, berdistribusi normal \\
\hline Posttest Kelas Eksperimen & 0,114 & Sig. $>0,05$, berdistribusi normal \\
\hline Posttest Kelas Kontrol & 0,082 & Sig. $>0,05$, berdistribusi normal \\
\hline
\end{tabular}

Berdasarkan tabel di atas Signifikansi lebih dari 0.05 maka dapat disimpulkan bahwa data kemampuan berpikir kritis siswa pada kelas eksperimen dan kelas kontrol berdistribusi normal.

Setelah dilakukan uji normalitas, kemudian dilakukan uji homogenitas. Berikut hasil uji homogenitas varian data pretest dan posttest pada kelas eksperimen maupun kelas kontrol dibantu program SPSS pada Tabel 2.

Tabel 3. Hasil Uji Homogenitas Kelas Eksperimen dan Kelas Kontrol

\begin{tabular}{|c|c|c|c|}
\hline Data & Kelompok penelitian & Statistik levene & Hasil (Sig.) \\
\hline \multirow{2}{*}{ Pretest } & Eksperimen & \multirow{2}{*}{1,145} & \multirow{2}{*}{0.291} \\
\hline & Kontrol & & \\
\hline \multirow{2}{*}{ Postetst } & Eksperimen & \multirow{2}{*}{3,491} & \multirow{2}{*}{0,069} \\
\hline & Kontrol & & \\
\hline
\end{tabular}

Berdasarkan tabel di atas Signifikansi lebih dari 0.05 maka dapat disimpulkan bahwa data kemampuan berpikir kritis siswa pada kelas eksperimen dan kelas kontrol memiliki varians yang homogen. Setelah data memenuhi uji normalitas dan uji homogenitas, maka analisis yang digunakan adalah $U j i-t$ dengan bantuan SPSS, seperti pada tabel 3 berikut.

Tabel 4.

Hasil Perhitungan Uji Independent Sample T-Test.

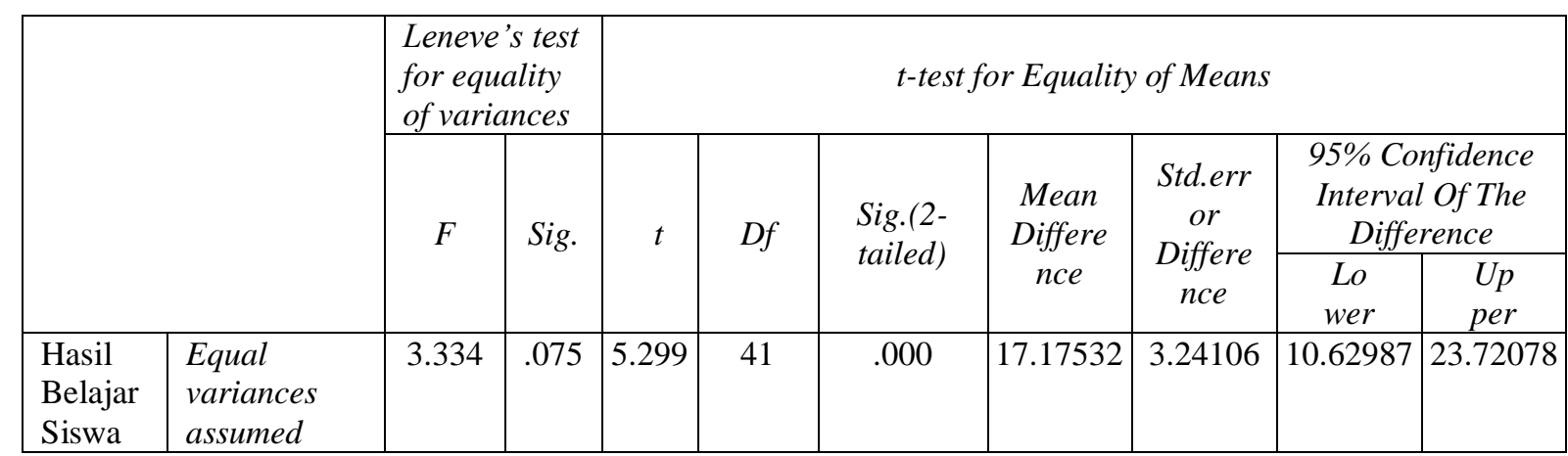




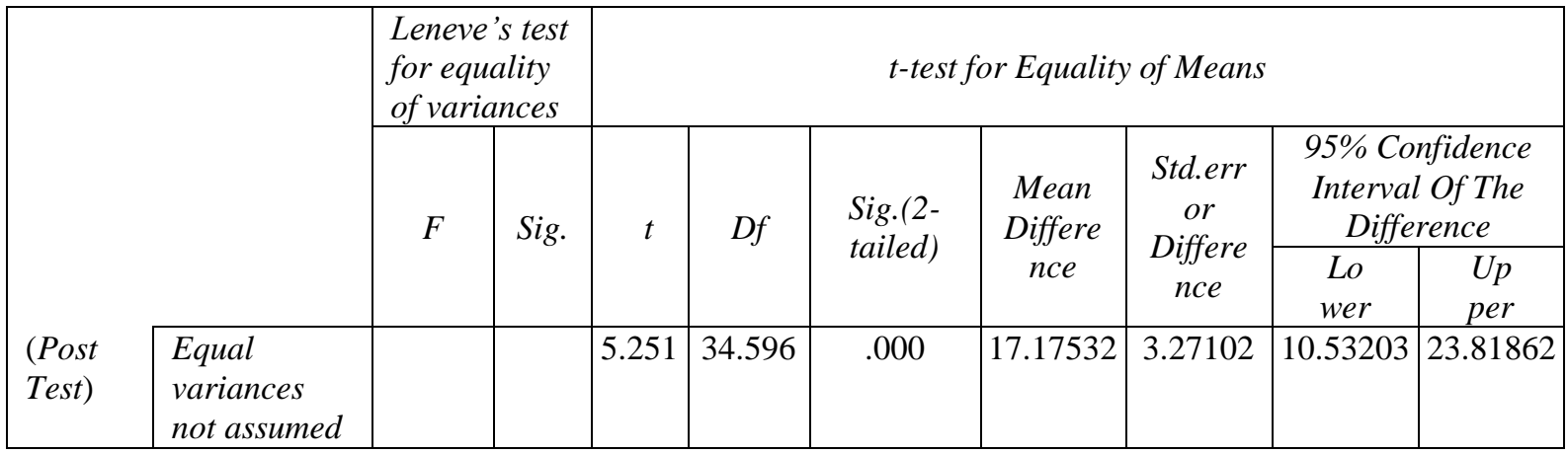

Berdasarkan perhitungan menggunakan SPSS 20 di atas, terlihat bahwa nilai Sig. $=0,075>$ 0,05 , maka $\mathrm{H}_{0}$ ditolak atau terima $\mathrm{H}_{1}$. Ini berarti bahwa rata-rata skor kemampuan berpikir kritis siswa yang menggunakan media pembelajaran interaktif berbasis strategi metakognitif lebih tinggi dibandingkan dengan kemampuan berpikir kritis siswa yang tidak menggunakan media pembelajaran interaktif berbasis strategi metakognitif. Artinya dapat dikatakan bahwa pembelajaran dengan menggunakan media pembelajaran interaktif berbasis strategi metakognitif lebih efektif dibandingkan dengan pembelajaran yang tidak menggunakan media pembelajaran interaktif berbasis strategi metakognitif.

\section{KESIMPULAN}

Hasil perhitungan validitas oleh ahli materi diperoleh nilai presentase sebesar $84,01 \%$ yang termasuk dalam kategori Baik. Sedangkan hasil validitas yang dilakukan oleh ahli media yang menunjukkan hasil presentase sebesar 95,45\% yang dapat disimpulkan bahwa nilai tersebut termasuk dalam kategori sangat baik. Dari hasil tersebut dapat disimpulkan bahwa media yang di validasi dapat dikatakan layak untuk digunakan dalam proses pembelajaran.

Selanjutnya Dari perhitungan menggunakan SPSS 20 di atas, terlihat bahwa nilai Sig. $=0,075>$ 0,05 , maka $\mathrm{H}_{0}$ ditolak atau terima $\mathrm{H}_{1}$. Ini berarti bahwa rata-rata skor kemampuan berpikir kritis siswa yang menggunakan media pembelajaran interaktif berbasis strategi metakognitif lebih tinggi dibandingkan dengan kemampuan berpikir kritis siswa yang tidak menggunakan media pembelajaran interaktif berbasis strategi metakognitif, maka dapat disimpulkan bahwa pengembangan media pembelajaran interaktif berbasis strategi metakognitif layak digunakan serta lebih efektif dalam meningkatkan kemampuan berpikir kritis siswa.

Kemudian hasil pengembangan media pembelajaran interaktif ini tentunya masih banyak kekurangan dan keterbatasan, yaitu materi yang dikembangkan masih terbatas pada materi barisan dan deret. Oleh karena itu perlu dilakukan pengembangan lanjutan terkait dengan media pembelajaran interaktif untuk materi matematika yang lain.

\section{DAFTAR PUSTAKA}

Ardhianti, M. (2015). Penerapan Media Boneka Tangan dalam Pembelajaran Mengonversi Teks 
Laporan Hasil Observasi Menjadi Teks Dialog pada Siswa Sekolah Menengah Atas. Buana Pendidikan: Jurnal Fakultas Keguruan Dan Ilmu Pendidikan, 11(20), 71-79.

Ennis, R. H. (1996). Critical Thinking Dispositions: Their Nature and Assessability. Informal Logic, $18(2), 165-182$.

Harto, D. B. (2008). Multimedia Intreraktif. Semarang : Universitas Negeri Semarang.

Hasnunidah, N. (2011). Keterampilan Berpikir Kritis Siswa SMP Pada Penggunaan Media Maket Melalui Contextual Teaching and Learning. Prosiding Seminar Nasional Pendidikan MIPA 2011 FKIP Unila.

Ivers, K. S., \& Barron, A. E. (2002). Multimedia Projects in Education: Designing,Producing, and Assessing. Libraries Unlimited Englewood, CO.

Magno, C. (2010). The Role of Metacognitive Skills in Developing Critical Thinking. Metacognition and Learning, 5(2), 137-156.

Malahayati, E. N., Corebima, A. D., \& Zubaidah, S. (2015). Hubungan Keterampilan Metakognitif dan Kemampuan Berpikir Kritis dengan Hasil Belajar Biologi Siswa SMA dalam Pembelajaran Problem Based Learning (PBL). Jurnal Pendidikan Sains, 3(4), 178-185.

Mayer, R. E. (2002). Cognitive Theory and The Design of Multimedia Instruction: An Example of The Two-Way street between cognition and nstruction. New Directions for Teaching and Learning, 2002(89), 55-71.

Miarso, Y. (2005). Menyemai benih teknologi pendidikan. Pustekom Diknas.

Munadi, Y. (2013). Media Pembelajaran. Sebuah Pendekatan Baru. Jakarta: Gaung persada press.

Özsoy, G., \& Ataman, A. (2017). The Effect of Metacognitive Strategy Training on Mathematical Problem Solving Achievement. International Electronic Journal of Elementary Education, 1(2), $67-82$.

Peter, E. E. (2012). Critical thinking: Essence for teaching mathematics and mathematics problem solving skills. African Journal of Mathematics and Computer Science Research, 5(3), 39-43.

Saricam, H., \& Ogurlu, Ü. (2015). Metacognitive Awareness and Math Anxiety in Gifted Students. Cypriot Journal of Educational Sciences, 10(4), 338-348.

Schraw, G. (1998). Promoting GeneralMetacognitive Awareness. Instructional Science, 26(1-2), $113-125$.

Slavin, R. E. (2006). Educational Psychology Theory and Practice Eight Edition. USA: Library of Congres Cataloging in Publication Data.

Suheri. (2006). Animasi Multimedia Pembelajaran. Jurnal Media Teknologi. Universitas Surya Kencana.

Tavakoli, H., \& Koosha, M. (2016). The effect of explicit metacognitive strategy instruction on reading comprehension and self-efficacy beliefs: The case of Iranian University EFL students.

Tinio, V. L. (2003). Information and Communication Tecnologie in Education. e-ASEAN Task Force. http://www.apdip.net/publications/iespprimers/ICTinEducation.pdf), diakses pada 16 Februari 2018

Wahidin, U., \& Syaefuddin, A. (2018). Media Pendidikan dalam Perspektif Pendidikan Islam. Edukasi Islami: Jurnal Pendidikan Islam, 7(01), 47-66. 